\title{
Boron Isotope Dilution in Cellular Fractions of Coffee Leaves Evaluated by Inductively Coupled Plasma Mass Spectrometry with Direct Injection Nebulization (DIN-ICP-MS)
}

\author{
Ana Cláudia S. Bellato, Amauri A. Menegário and Maria Fernanda Giné * \\ Centro de Energia Nuclear na Agricultura, Universidade de São Paulo, Av. Centenário 303, CP 96, \\ 13400-970 Piracicaba-SP, Brazil
}

\begin{abstract}
A diluição isotópica do B enriquecido em 94,14 átomos $\%$ em ${ }^{10} \mathrm{~B}$ fornecido durante o cultivo de mudas de cafeeiro foi avaliada na parede celular, núcleo e cloroplastos de células foliares. Para isto foi necessária a determinação de ${ }^{11} \mathrm{~B} /{ }^{10} \mathrm{~B}$ em pequenos volumes de amostras conseguidas pelo processo de fracionamento por centrifugação diferenciada. As determinações isotópicas foram efetuadas por espectrometria de massas com fonte de plasma acoplado indutivamente (ICP-MS) utilizando-se nebulizador de injeção direta (DIN). Razões isotópicas de B entre 1,002 e 1,326 foram determinadas em $50 \mu \mathrm{L}$ das amostras enriquecidas com precisão caracterizada por $\mathrm{RSD}<1,5 \%$. As concentrações de B encontradas nas frações celulares variaram entre 3,3 e 10,8 $\mu \mathrm{g} \mathrm{g}^{-1}$, e em média os átomos $\%$ de ${ }^{10} \mathrm{~B}$ foram 46,$7 ; 44,5$ e 48,8 na parede celular, núcleo e cloroplasto, respectivamente. $\mathrm{O}$ limite de detecção foi estimado em $0,5 \mathrm{ng} \mathrm{B} \mathrm{mL}^{-1}$.
\end{abstract}

Enriched ${ }^{10} \mathrm{~B}$ (94.14 atom \%) was supplied to coffee plantlets for three months. Then boron isotope ratios were determined in the leaf cell compartments, cell wall, nuclei and chloroplast, after a sub-cellular fractionation procedure. The isotopic measurements were performed by Inductively Coupled Plasma Mass Spectrometry (ICP-MS) provided with a direct injection nebulizer (DIN), introducing a sample volume of $50 \mu \mathrm{L}$. Isotopic ratios from 1.002 to 1.326 were determined with precision characterized by RSD lower than $1.5 \%$ for the enriched cell fractions with B concentrations ranging from 3.3 to $10.8 \mu \mathrm{g} \mathrm{g}^{-1}$. The detection limit $(3 \sigma)$ was $0.5 \mathrm{ng} \mathrm{B} \mathrm{mL}^{-1}$. The average enrichments in ${ }^{10} \mathrm{~B}$ atom $\%$ found in the cell walls, nuclei and chloroplasts were $46.7,44.5$ and 48.8 , respectively.

Keywords: isotope dilution, inductively coupled plasma mass spectrometry, biological cell fractionation, boron isotope ratios, plant analysis

\section{Introduction}

The interest in determining traces of boron has increased in recent years, since boron is an essential element for plants and may also be essential for animals and humans. ${ }^{1}$ Besides, the application of ${ }^{10} \mathrm{~B}$ in neutron capture therapy (BNCT) is increasing as well as its isotopic determination in biological tissues. ${ }^{2}$

Thermal ionization mass spectrometry (TI-MS) may be used for boron isotope ratio measurements with precisions ranging from 0.2 and $0.3 \% .^{3}$ The main disadvantage of this method is the time-consuming sample preparation. With inductively coupled plasma mass spectrometry (ICP-MS) boron concentrations and isotope ratios are determined with minimal requirements in sample preparation. ${ }^{4}$

*e-mail: mfgine@cena.usp.br
The principal concerns when using ICP-MS for B isotopic determinations concern memory effects and mass discrimination. Memory effects are mainly due to interactions of B with the heated quartz torch. Some authors use washout times of several minutes to reduce boron memory. ${ }^{5-6}$ Others use a sodium fluoride solution, ${ }^{7}$ Triton $\mathrm{X}-100$ surfactant $^{8}{ }^{\text {mannitol }^{9}}$ or ammonia ${ }^{10}$ as washing agents. These methods slowly remove the memory effect when solutions with more than $0.5 \mathrm{mg} \mathrm{L}^{-1}$ of boron are analyzed. No memory effect occurs using direct injection nebulization (DIN). This device promotes liquid sample transport inside a capillary by pumping at high pressure, introducing its aerosol into the plasma, avoiding contact with the torch and spray chambers. ${ }^{11-12}$ Mass discrimination between ${ }^{11} \mathrm{~B}$ and ${ }^{10} \mathrm{~B}$ is accentuated due to the $10 \%$ isotopic mass difference and arises during ion transport caused by instrumental adjustments or by the sample matrix. ${ }^{13}$ The instrumental effect is corrected by analyzing a reference standard with a certified ${ }^{11} \mathrm{~B} /{ }^{10} \mathrm{~B}$ ratio (NIST SRM 951). ${ }^{14}$ 
The sample matrix effect on mass discrimination can be corrected using internal standards. ${ }^{12,15-16}$

Also, for low-resolution quadrupole-based mass spectrometers, spectral overlap of ${ }^{12} \mathrm{C}$ on ${ }^{11} \mathrm{~B}$ could occur, which is relevant for $\mathrm{B}$ isotope measurements in biological digests. Evans and Krahenbuhl ${ }^{7}$ noted a significant interference of ${ }^{12} \mathrm{C}$ on $\mathrm{B}$ when analyzing microwavedigested samples using ICP-MS in the normal resolution mode $(0.8 \mathrm{u})$. In the high-resolution mode $(0.6 \mathrm{u})$ Gregoire $^{14}$ reported good results for geological solutions, but not for biological digests. ${ }^{17}$

In the present paper, intrinsic ${ }^{10} \mathrm{~B}$ labeled coffee leaves were submitted to a sub-cellular fractionation procedure. Inductively coupled plasma mass spectrometry with a direct injection nebulizer was used to determine boron isotope ratios from the separated cell walls, nuclei and chloroplasts.

\section{Experimental}

\section{Apparatus}

A VG plasma Quad PQII ICP-MS, (VG Elemental, Winsford, Cheshire, UK) was used for isotopic measurements. A computer controlled direct injection nebulizer system, DIN, model Microneb 2000 (CETAC Technologies, Omaha, NE, USA) provided with two sixport solenoid valves, a gas displacement pump (GDP), and a quartz torch formed by four concentric tubes was used. A fused-silica capillary is inside the middle torch tube, and with the other tubes the nebulization, the auxiliary and the plasma gases are introduced. The ICP-MS and DIN operating conditions are shown in Table 1. An inductively coupled plasma optical emission spectrometer (ICP-OES) Optima 3000 DV (Perkin Elmer, Norwalk, USA) was

Table 1. DIN-ICP-MS operating conditions

\begin{tabular}{llc}
\hline Plasma & Forward power, W & 1350 \\
& Reflected power, W & $<5$ \\
Argon flow rate, & Plasma & 12.0 \\
L min m $^{-1}$ & Auxiliary & 0.7 \\
& Nebulizer & 0.2 \\
DIN & GDP pressure, kPa & 827 \\
& Nebulizer pressure, kPa & 550 \\
& Capillary, i.d.(mm) & 0.075 \\
& Carrier & $2 \%(\mathrm{v} / \mathrm{v}) \mathrm{HNO}$ \\
& & \\
Data acquisition & Detection Mode & Scan $(\mathrm{m} / \mathrm{z}) 10-11$ \\
& Channels/amu & 19 \\
& Dwell Time, $\mu$ s & 320 \\
& Total acquisition time, s & 30 \\
\hline
\end{tabular}

employed for B and C determination at $249.773 \mathrm{~nm}$ and $193.3 \mathrm{~nm}$, respectively. For sample preparation a Sorvall Super T21 refrigerated centrifuge (Du Pont, Wilmington, USA), a 801851 optical microscope (Nikon, Tokio, Japan) and silicone-treated paper (CalBiochem, San Diego, USA) were utilized for cell fractionation. A NT 245 water bath (Nova Técnica, Piracicaba, Brazil) and a 259E mechanical shaker (Fanem, São Paulo, Brazil) were used for sample preparation.

\section{Reagents and solutions}

Concentrated nitric and hydrochloric acids, proanalyze quality (Merck, Darmstadt, Germany), purified by sub-boiling distillation, and water deionized to $18.2 \mathrm{M} \Omega \mathrm{cm}$ in a Milli-Q system (Millipore, Bedford, MA, USA) were used throughout.

A stock solution of $\mathrm{C}\left(10000 \mathrm{mg} \mathrm{L}^{-1}\right)$ was prepared from $(\mathrm{COOH})_{2} \cdot 2 \mathrm{H}_{2} \mathrm{O}$ (Merck, Darmstadt, Germany). Stock solutions of $\mathrm{B}\left(1000 \mathrm{mg} \mathrm{L}^{-1}\right)$ were prepared from $\mathrm{H}_{3} \mathrm{BO}_{3}$ isotopic certified reference material, from National Institute of Standard and Technology (NIST SRM-951) and boric acid enriched in ${ }^{10} \mathrm{~B}$ (50 atom \%), produced by the Instituto de Engenharia Nuclear (IEN, Rio de Janeiro, Brazil).

Working solutions of $\mathrm{B}\left(25 \mu \mathrm{g} \mathrm{L}^{-1}\right)$ and $\mathrm{B}+\mathrm{C}\left(25 \mu \mathrm{g} \mathrm{L}^{-1}+\right.$ $2000 \mathrm{mg} \mathrm{L}^{-1}$ ) were prepared by appropriate dilutions in $1 \mathrm{~mol} \mathrm{~L}^{-1} \mathrm{HCl}$ from the certified B stock solutions and $\mathrm{C}$ stock solution. Solutions of $2 \% \mathrm{v} / \mathrm{v} \mathrm{HNO}_{3}, 0.05 \mathrm{~mol} \mathrm{~L}^{-1}$ Tris- $\mathrm{HCl}$ (tris-[hydroxymethyl] aminomethane, Sigma, St. Louis, USA) and $0.3 \mathrm{~mol} \mathrm{~L}^{-1}$ sucrose (Merck), adjusted to $\mathrm{pH}$ 7, were also prepared.

\section{Samples}

Coffee plantlets were cultivated in nutrient solutions for 3 months. Nine plantlets received $\mathrm{H}_{3} \mathrm{BO}_{3}$ enriched with 94.14 atom $\%{ }^{10} \mathrm{~B}$ (enriched sample), and four plantlets received $\mathrm{H}_{3} \mathrm{BO}_{3}$ in natural isotope composition (control sample). At the end of the treatment plants were collected and separated into leaves, stems and roots.

\section{Sample preparation}

Samples of leaves, stems and roots from six plants were rinsed in deionized water and dried at $50{ }^{\circ} \mathrm{C}$ in a drying oven. The dried samples were ground until passing through a 20-mesh screen. After that, the extraction of B was carried out by using $100 \mu \mathrm{g}$ of sample mixed with $5 \mu \mathrm{L}$ of $1 \mathrm{~mol} \mathrm{~L}^{-1}$ $\mathrm{HCl}$ and heating in a water bath at $80{ }^{\circ} \mathrm{C}$ for $15 \mathrm{~min}$. The cold solutions were shaken for $1 \mathrm{~h}$ at $250 \mathrm{rpm}$ and filtered (Whatman-40). 
The leaves of seven plants were destined for cell fractionation and isotopic analysis. The cell fractionation steps are shown in Figure 1.

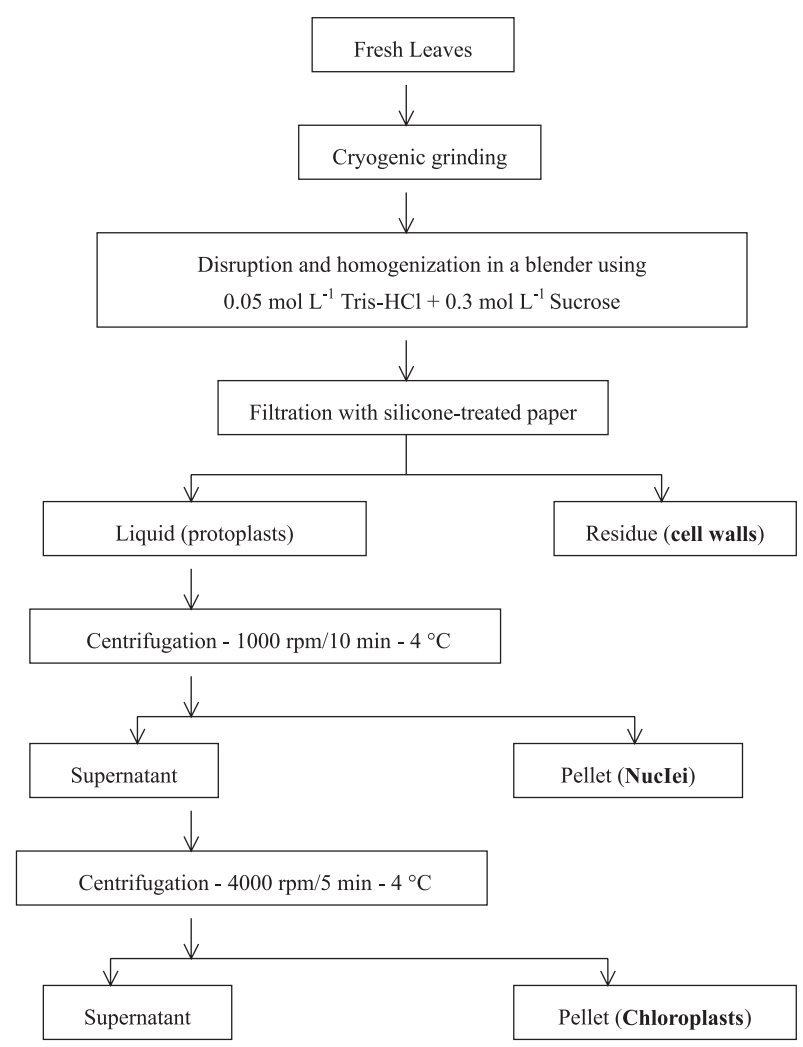

Figure 1. Scheme of the cell fractionation process used in this research to separate cell walls, nuclei and chloroplasts of coffee leaves.

The fractionation procedure was performed at coldroom temperature $\left(10{ }^{\circ} \mathrm{C}\right)$ using $\mathrm{N}_{2}$ cryogenic grinding and a refrigerated centrifuge in order to minimize possible enzymatic changes in the sub-cellular components. The rupturing of the cell wall was performed in a blender using Tris- $\mathrm{HCl}$ and sucrose. This medium preserved the structure of the cell components since it constituted of an isotonic solution that guarantees the osmotic activity while the buffering characteristics of Tris- $\mathrm{HCl}$ maintained the $\mathrm{pH}$ during the release of organic acid from the ruptured vacuoles. Confirmation of each separated component was corroborated by optical microscopy. Then, the B present in the separated fractions (cell walls, nuclei and chloroplasts) were extracted with $1 \mathrm{~mol} \mathrm{~L}^{-1} \mathrm{HCl}$. A blank solution of the extractor was used to determine the limit of detection.

\section{Results and Discussion}

Total B concentrations were determined in leaves, stems and roots from three replicates of two controls and four plants that received the enriched ${ }^{10} \mathrm{~B}$. No difference in total $\mathrm{B}$ concentrations was noticed between samples with and without enriched B. The B concentrations were $78.3 \pm$ $2.6 \mu \mathrm{g} \mathrm{g}^{-1}$ in leaves, $55.6 \pm 2.6 \mu \mathrm{g} \mathrm{g}^{-1}$ in stems and $69.1 \pm$ $2.4 \mu \mathrm{g} \mathrm{g}^{-1}$ in roots.

From $2 \mathrm{~g}$ of fresh leaves and after the fractionation steps, around $800 \mu \mathrm{g}$ of cell walls, $200 \mu \mathrm{g}$ of nuclei and $300 \mu \mathrm{g}$ chloroplasts were separated. Sub-samples of $100 \mu \mathrm{g}$ were extracted, producing around $4 \mathrm{~mL}$ of solution for determining total $\mathrm{B}$ concentration and the isotope ratios. Results presented in Table 2 correspond to total $\mathrm{B}$ determined by ICP-OES in each cellular fraction of the different samples. The low variance of results in each fraction reflects the high reproducibility of the process. The average content of $\mathrm{B}$ in the fractions was around $20 \mu \mathrm{g}$ per g of fresh leaves with $70 \%$ of humidity, that means that $83 \%$ of the total B is in the analyzed cell compartments.

Table 2. Total boron concentration $\left(\mu \mathrm{g} \mathrm{g}^{-1}\right)$ in the cell fractions (Mean values, $n=6$ )

\begin{tabular}{lrcc}
\hline Coffee leaves & \multicolumn{3}{c}{ Mean \pm SD } \\
\cline { 2 - 4 } & \multicolumn{1}{c}{ Cell walls } & \multicolumn{1}{c}{ Nuclei } & Chloroplasts \\
\hline Control - 01 & $10.8 \pm 0.3$ & $5.2 \pm 0.1$ & $3.3 \pm 0.1$ \\
Control - 02 & $9.9 \pm 0.4$ & $5.9 \pm 0.2$ & $3.1 \pm 0.1$ \\
Enriched - 01 & $11.6 \pm 0.2$ & $6.1 \pm 0.1$ & $3.3 \pm 0.1$ \\
Enriched - 02 & $10.4 \pm 0.3$ & $5.6 \pm 0.1$ & $3.2 \pm 0.1$ \\
Enriched - 03 & $9.3 \pm 0.1$ & $5.2 \pm 0.1$ & $3.2 \pm 0.1$ \\
Enriched - 04 & $10.6 \pm 0.1$ & $6.3 \pm 0.1$ & $3.2 \pm 0.1$ \\
Enriched - 05 & $11.4 \pm 0.3$ & $5.4 \pm 0.1$ & $3.0 \pm 0.1$ \\
\hline
\end{tabular}

The small sample volumes obtained after B extraction were used to perform several analyses using the DIN system. Injected volumes of 20,50 and $100 \mu \mathrm{L}$ of a $25 \mu \mathrm{g} \mathrm{L}^{-1} \mathrm{~B}$ standard solution were transported through the capillary to the plasma by the $2 \% \mathrm{v} / \mathrm{v} \mathrm{HNO}_{3}$ carrier solution pressurized by gas at $827 \mathrm{kPa}$. Under these conditions the transient signals presented in Figure 2 were attained monitoring $m / z 11$. A rapid increase after sample injection, a steady state dependent on the injected volume and a long slowdown characterize the peaks. Returning the injection valve to the original position the baseline is attained faster. The $\mathrm{B}$ isotope ratios were measured during $30 \mathrm{~s}$, thus, a $50 \mu \mathrm{L}$ sample volume was chosen. The ICPMS data acquisition was synchronized with the DIN injection, programming a delay of $5 \mathrm{~s}$ to start acquisition after sample injection to ensure that data were collected at the peak maximum.

Results of boron isotope measurements by ICP-MS were affected by mass discrimination due to the gas pressure 


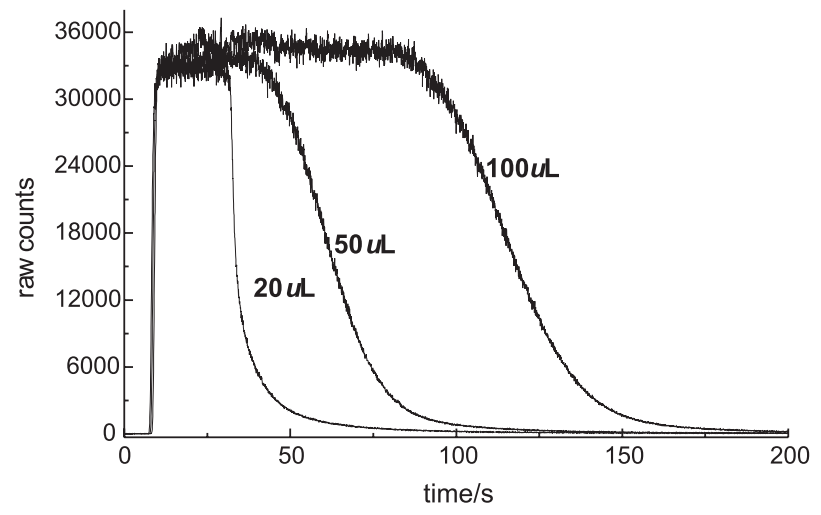

Figura 2. Transient signals at $\mathrm{m} / \mathrm{z}, 11$ obtained with ICP-MS by injection using DIN of discrete volumes $(25,50$ and $100 \mu \mathrm{L})$ of a $25 \mu \mathrm{g} \mathrm{L}^{-1}$ solution of $\mathrm{B}$.

forming the aerosol by DIN, as shown in Figure 3. The nebulization conditions affect ${ }^{10} \mathrm{~B}$ and ${ }^{11} \mathrm{~B}$ measurements, consequently, the ${ }^{11} \mathrm{~B} /{ }^{10} \mathrm{~B}$ ratio. The closest isotope ratio for the certified standard solution NIST 951 (4.044) was

(a)

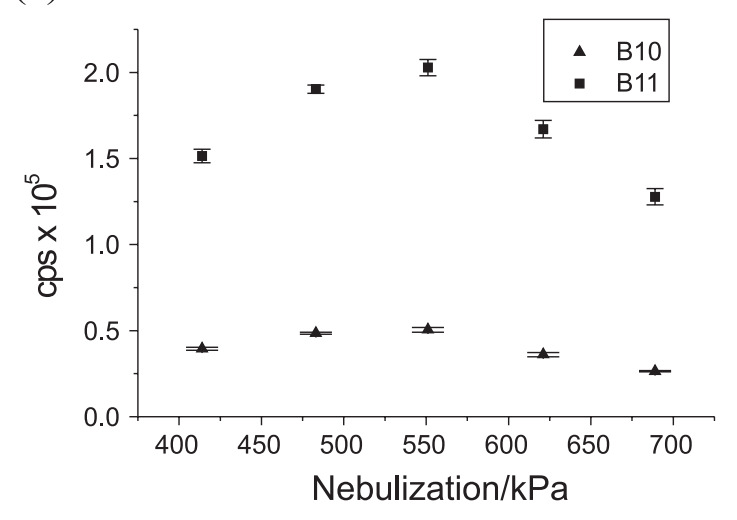

(b)

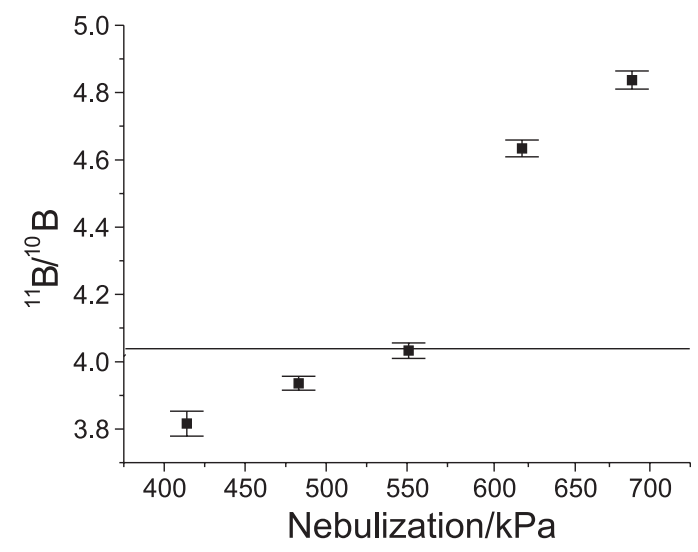

Figure 3. Effect of DIN gas nebulization pressure on B isotopes signals (a) Sensitivity in counts per seconds (cps) for ${ }^{11} \mathrm{~B}$ and ${ }^{10} \mathrm{~B}$ (b) ${ }^{11} \mathrm{~B} /{ }^{10} \mathrm{~B}$ measurements. obtained at $550 \mathrm{kPa}$. The total mass bias on $\mathrm{B}$ isotope ratio determination was calculated by comparing the reference and measured values of a $25 \mu \mathrm{g} \mathrm{L}^{-1}$ of NIST 951. The mass bias was less than $3 \%$, which was lower than reported early values. ${ }^{18-19}$ The detection limit of $0.5 \mathrm{ng} \mathrm{B} \mathrm{mL}-1$ was calculated from data $(3 \sigma)$ obtained by 10 sequential measurements at $\mathrm{m} / \mathrm{z} 10$ of the blank solution.

The residual carbon contents in the sub-cellular solutions determined by ICP-OES were lower than $2000 \mathrm{mg} \mathrm{L}^{-1}$. Adjusting the resolution to $0.6 \mathrm{u}$ using the criteria of $10 \%$ peak height, the overlap of ${ }^{12} \mathrm{C}$ on the ${ }^{11} \mathrm{~B}$ signals in the ICP-MS was minimized. This parameter was defined by analyzing a solution containing $25 \mu \mathrm{g} \mathrm{L}^{-1}$ of the IEN standard $\left({ }^{11} \mathrm{~B} /{ }^{10} \mathrm{~B}=1\right)$ alone and with $2000 \mathrm{mg} \mathrm{L}^{-1}$ of C.

Results presented in Table 3 correspond to B isotope ratios corrected for instrumental mass bias, following the recommendations of Gregoire. ${ }^{14}$ The atom $\%$ of ${ }^{10} \mathrm{~B}$ were calculated from the relation: atom $\%{ }^{10} \mathrm{~B}=100 / \mathrm{R}+1$, with $\mathrm{R}$ being the isotope ratio. The precision of the ${ }^{11} \mathrm{~B} /{ }^{10} \mathrm{~B}$ measurements was characterized by RSD lower than $1.5 \%$. The control samples presented isotope ratios from 3.976 to 4.062 , which are close to those reported in other agricultural studies. ${ }^{4}$ Isotope ratios ranges from 1.111 to 1.171 in the cell walls, from 1.195 to 1.340 in the nuclei and from 0.9920 to 1.074 in the chloroplast samples were

Table 3. Boron isotope ratios in the cell fractions of the samples

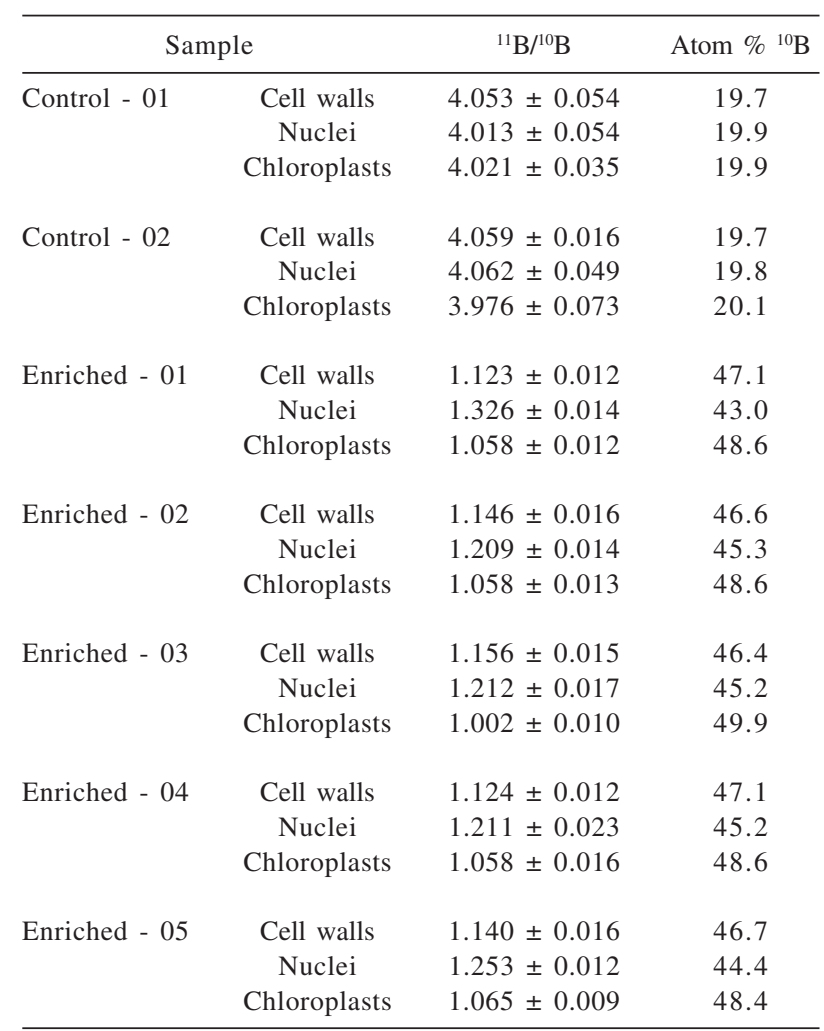


found. These ratios reflect a slight discrimination between fractions. In terms of atom $\%{ }^{10} \mathrm{~B}$, the chloroplasts present values on average 2 atom $\%$ higher than the cell wall and 4 atom $\%$ more than the nuclei. The ${ }^{10} \mathrm{~B}$ atom $\%$ found in the samples was two times higher than that of the controls, as a consequence of the addition of $3 \mathrm{mg}$ (94.14 atom \%) of ${ }^{10} \mathrm{~B}$ per plant.

\section{Conclusions}

The feasibility of evaluation of the isotope dilution of ${ }^{10} \mathrm{~B}$ in compartments produced by cell fractionation of leaves was demonstrated by obtaining reliable experimental data using ICP-MS and DIN.

In terms of comparison with the control sample, the ${ }^{10} \mathrm{~B}$ enrichment was approximately 29, 27 and 25 atom \% in the chloroplast, cell wall and nucleus fractions, respectively, which were well discriminated by the proposed methodology.

\section{Acknowledgements}

This work received financial support from FAPESP (Fundação de Amparo à Pesquisa do Estado de São Paulo) and CNPq/ PRONEX.

\section{References}

1. Sah, R.N.; Brown, P.H.; Microchemical J. 1997, 56, 285.

2. Moreton, J.A.; Delves, H.T.; J. Anal. At. Spectrom. 1999, 14, 1545.

3. Vanderpool, R.A.; Johnson, P.E.; J. Agric. Food Chem. 1992, $40,462$.

4. Vanderpool, R.A.; Hoff, D.; Johnson, P.E.; Environm. Health Persp. 1994, 102, 13.
5. Ward, N.I.; Abou-Shakra, S.; Durrant, S.F.; Biol. Trace Elemental Res. 1990, 26, 177.

6. Vanhoe, H.; Dams, R.; Vandecasteele, C.; Versieck, J.; Anal. Chim. Acta. 1993, 281, 401.

7. Evans, E.; Krahenbuhl, U.; J. Anal. At. Spectrom. 1994, 9, 1249.

8. Probst, T.U.; Berryman, N.G.; Lemmen, P.; Weissfloch, L.; Auberger, T.; Gabel, D.; Carlsson, J.; Larsson, B. J. Anal. At. Spectrom. 1997, 12, 1115.

9. Sun, D.H.; Ma, R.L.; McLeod, C.W.; Wang, X.R.; Cox, A.G.; J. Anal. At. Spectrom. 2000, 15, 257.

10. Al-Ammar, A.; Gupta, R. K.; Barnes, R. M.; Spectrochim. Acta - Part B 1999, 54, 1077.

11. Smith, F.; Wiederin, D.R.; Houk, R.S.; Egan, C.B.; Serfass, R.E.; Anal. Chim. Acta, 1991, 248, 229.

12. Bellato, A.C.S.; Menegário, A.A.; Giné, M.F.; Commun. Soil Sci. Plant Anal. 2001, 32, 1981.

13. Evans, E.H.; Giglio, J.J.; J. Anal. At. Spectrom. 1993, 8, 1.

14. Gregoire, D.C; Anal. Chem. 1987, 59, 2479.

15. Gregoire, D.C.; J. Anal. At. Spectrom. 1990, 5, 623.

16. Al-Ammar, A.; Reitznerová, E.; Barnes, R. M.; Spectrochim. Acta - Part B 2000, 55, 1861.

17. Nyomora, A.M.; Sah, R.N.; Brown, P.H.; Fresenius J. Anal. Chem. 1997, 357, 1185.

18. Porteous, N.C.; Walsh, J.N.; Jarvis, K.E.; Analyst 1995, 120, 1397.

19. Heumann, K. G.; Gallus, S.M.; Rädlinger G.; Vogl, J.; J. Anal. At. Spectrom. 1998, 13, 1001.

Received: October 19, 2002

Published on the web: March 21, 2003

FAPESP helped in meeting the publication costs of this article. 